\title{
The Role of Off-Farm Employment in Tropical Forest Conservation: Labor, Migration, and Smallholder Attitudes Toward Land in Western Uganda
}

\author{
Brad G. Mulley \\ and \\ Jon D. Unruh
}

\begin{abstract}
The potential for off-farm employment (OFE) to contribute significantly to forest conservation in the tropics is a widely held logic among donors, governments, and social scientists. While an aggregate level examination of OFE cases can support this logic, there is disagreement as to the operative aspects of specific linkages and assumptions. This study examines the case of the tea industry in western Uganda, and uses a combination of fieldwork and remote sensing to pursue a more nuanced examination of the role of migration and non-monetary aspects of OFE on forest conservation in both a national park and unprotected forest contexts.
\end{abstract}

Results indicate that the tea industry does serve as an off-farm employer to a limited number of local smallholders but these benefits are offset by the industry's overwhelming dependence on migrant labor which sees OFE as temporary, then seeks to settle locally. There is also evidence that the tea industry is contributing to conservation efforts of Kibale National Park by unintentionally serving as a physical buffer zone, which inhibits both human encroachment on the park and wildlife encroachment on smallholder crops. The latter represents a site-specific phenomenon that holds much potential for future management plans of the area and exemplifies the importance of considering the sitespecific circumstances associated with off-farm employment development.

Keywords: Off farm employment, forest, conservation, Uganda, migration

\section{Introduction}

Agricultural expansion by small-scale agriculturalists in the tropics is widely viewed as one of the most formidable threats to protected forest areas and a leading cause of deforestation. Off-farm employment (OFE) however is thought to mitigate agricultural expansion by removing smallholders from agriculture or decreasing dependence on agriculture, thus decreasing deforestation and improving household incomes and peoplepark relations. The majority of studies investigating the relationship between off-farm employment and deforestation have focused on land use change as a function of household income change. While donor policies and numerous studies have followed the logic that increased incomes via OFE will affect land use decisions of smallholders, the realities of OFE operation can be much less straightforward--to the degree that simply 
providing for increased incomes may not in many cases decrease deforestation or decrease pressure on protected areas. This article explores two primary complexities not adequately addressed in the OFE literature - migration, and non-monetary aspects of OFE for smallholders. The research examines whether the tea industry in western Uganda, a major source of off-farm employment, reduces pressure on neighboring Kibale National Park (KNP) and nearby unprotected forest areas. The intention here is not to prove or disprove the complex topic of OFE and conservation, but rather to contribute to a more nuanced consideration of OFE, and to articulate circumstances where the outcomes are other than expected. And while migration and OFE has been considered elsewhere generally (e.g. Garrily et al 2000; Ericson et al 1999; Kaimowitz et al 1998), it is our attempt here to examine it more explicitly. The study uses a practical approach to landscape-scale analysis, which we believe to be a primary contribution of the article.

\section{Off-Farm Employment and Land Use}

The notion that OFE opportunities results in less deforestation by small scale agriculturalists is supported by a number of studies, and recommended by many. Godoy et al (1997a) found that among four Amerindian societies in Honduras and Bolivia, economic development in the form of raising cash crops on smallholder land increased deforestation while economic development in the form of OFE resulted in less deforestation and conclude, "increasing non-farm work causes deforestation to decline" (p. 876). Cervingi (1998) employed land use models of rural Mexico to find strong correlations between OFE and less forest conversion for agricultural plots. Bluffstone (1993) asserts that with a "perfect albeit low wage" off-farm labor market, an agro-forestry system in Nepal is stable even in an open access situation. Similar assertions regarding the relationship between OFE and deforestation are also reported in Bilsborrow and Walsh (2001), Holden (1993), Beaumont and Walker (1996), Shively and Martinez (2001), Ferrantino (1999), and Garrity et al. (2000). The dominant narrative emerging from the literature is that OFE reduces deforestation in two ways: 1) by reducing dependence on subsistence agriculture (increased incomes) thereby reducing the need to clear land; and 2) by labor competition - time spent as a wage laborer means less time is available for agriculture. The assumption that OFE leads to decreased pressure on forests, appears so accepted that scholars and development agencies recommend and pursue policies that generate OFE opportunities. A study by Angelsen and Kaimowitz (1999:84) states “...policies that favor rural wage increases and generate off-farm employment opportunities for rural people should reduce deforestation. Such policies should simultaneously conserve forests and diminish poverty." However in spite of the support that the idea receives, there remains disagreement regarding the precise relationship between income and deforestation, especially with regard to when deforestation purportedly begins to decline with increases in income (e.g., Shafik and Bandyopadhyay, 1992; Godoy et al., 1997b; Cropper and Griffiths, 1994; and Ferrantino, 1999). 
As Godoy et al. (1997b) point out, the primary approach to looking at OFE and conservation has been to measure deforestation rates over time, with little attention paid to the specific conditions under which deforestation in particular areas is increasing or decreasing. In spite of the apparent logic of OFE for deforestation, more information regarding the specific conditions that influence forest use decisions in the OFE context is greatly needed to gain a better understanding of the intricacies involved that result in different outcomes. For instance, does more integration into the cash economy alter the value communities hold for land-based natural resources? In societies focused largely on food and livelihood security as connected to land access and ownership, is there resistance to abandoning an agricultural lifestyle? What is the probability that the smallholder will remain in the labor force (and not return to agriculture) considering the influence of fluctuating markets and political instability?

Also absent from the OFE literature is an in-depth dialogue on the importance of recognizing the characteristics of different types of OFE and the different relationships that exist between local community circumstances and OFE opportunities. Godoy et al. (1997a) for example aggregate working with ranchers, loggers, and non-governmental organizations into one category - off-farm employment. Such an aggregate approach ignores the specifics attached to each type of employer. Wage differences, seasonal versus full-time work, migration patterns, and the land use strategies of the employer (especially if the employer itself is causing deforestation) are some of the issues that vary among different types of OFE, and that influence outcomes. This article explores OFE in the context of agribusiness - an industry not adequately addressed in the relevant literature, but of enormous importance in terms of conservation and OFE in rural areas. Because agribusiness endeavors (plantations, processing, etc.) tend to be located in areas of smallholder agriculture, and require a large workforce with skills matching those of small-scale farmers, they represent one of the largest employers of rural smallholders throughout the tropics ${ }^{1}$ (Williams and Karen, 1985; and Hardner and Rice, 2002).

\section{$\underline{\text { Kibale National Park }}$}

\section{Western Uganda}

Research took place in and around Kibale National Park (KNP) located in Kabarole district $^{2}$ in western Uganda (Figure 1). Kibale National Park comprises approximately $800 \mathrm{sq} \mathrm{km}$ of mid-latitude moist evergreen forest (Naughton-Treves, 1998). Figure 2 shows the boundaries of KNP and the villages visited during fieldwork. The population of Kabarole district consists of a variety of ethnic groups including Batoro, Bakiga, Bahororo, Banyankole, and Banyarwanda. While the Batoro are considered to be the

\footnotetext{
${ }^{1}$ Some plantations are purposely situated near tropical forests because they benefit from the cool moist environment provided by forests (UNEP 2001, Hardner and Rice 2002) making it all the more relevant to examine these in the context of OFE and conservation.

2 In 2000, Kabarole was split into four districts: Kabarole, Kyenjojo, Kibaale, and Kasese, but for the purposes of this study Kabarole will be referred to as the district where KNP is located because it contains the majority of KNP and the available literature refers to Kabarole as KNP's home district.
} 
local indigenous ethnic group (Nabuguzi and Edumunds, 1993; and Naughton-Treves, 1998), ${ }^{3}$ there is significant ethnic complexity in the numerous clans, themselves divided into two groups, the agriculturalists (majority) and the royal pastoralists, which include the chiefs (Naughton-Treves 1999).

In 1932, the British colonial government classified Kibale forest as a reserve with the goal of providing a sustainable source of hardwood. In 1993 Kibale forest was upgraded to national park status, the highest conservation status under Ugandan law (Feeney, 1998). The Park is home to over 60 species of mammalian fauna, including 12 primates, 325 bird species, and over 200 tree species, making it an international conservation priority (Uganda Wildlife Authority, 1996; and Naughton-Treves, 1998). From 1959 to 1990, the human population around the Park more than tripled posing a significant challenge to conservation efforts (World Bank, 1993). Agriculture is the main occupation of the area and common food crops include banana, groundnuts, cassava, beans and potato. To supplement their income, many farmers sell or trade portions of their food crops and many grow cash crops, including tea and tobacco. According to an analysis of 1988 aerial photographs by Mugisha (1994), subsistence agricultural plots surrounded approximately 58 percent of the area within $1.5 \mathrm{~km}$ of the forest boundary at that time (Naughton-Treves, 1998).

Although the park is divided into various zones including a multiple use zone where local communities are allowed limited use of forest resources, the overall management strategy is based on the exclusion of rural communities. As a result, local communities have developed resentment for the park due to decreased access to resources and the lack of legal support to protect crops from wildlife damage (Uganda Wildlife Authority, 1996; and Naughton-Treves, 1997, 1998). People-park relations are also problematic due to the eviction of some 35,000 people from the Kibale Forest Reserve and Game Corridor in April 1992. According to Feeney (1998), the eviction violated human rights and resulted in a number of deaths. Although many of those evicted were eventually settled in other districts, a large portion settled near the park and understandably have negative views towards the KNP. According to employees of the Ugandan Wildlife Authority (UWA), hostility among the neighboring communities is the greatest challenge to sustainable management (also Uganda Wildlife Authority, 1996). Since the Reserve was upgraded to a National Park in 1993, the Ugandan government and international donors have made substantial investments in enforcement and monitoring. Adding to enforcement are tourists and international researchers who frequent many areas of KNP and serve as proxy forest guards to some extent.

The majority of previous studies on KNP have focused on examining the diverse primate population of the area (e.g., Watts and Mitani, 2002) with little attention paid to humanenvironment interactions. To date there have been no in-depth studies on the relationship

\footnotetext{
${ }^{3}$ Kabarole is the former Toro kingdom - Toro referring to Batoro.
} 
between agribusiness endeavors and KNP. This is surprising considering the long history of the tea industry in the area and the close proximity of many estates to KNP.

\section{The tea industry around Kibale National Park}

Tea dominates much of the landscape bordering the northern portion of KNP. Tea producers in the area range from large multinational companies with hundreds of hectares, to smaller individually owned plots with holdings as small as 0.1 hectare. The major tea companies in the area are Rwenzori Commodities, Rwenzori Highlands, TAMTECO, and the Ugandan Tea Growers Corporation (UTGC)/Agri-Industrial Management Agency (AGRIMAG). While tea is primarily grown on company owned plantations, there is an increasing number of smallholder tea producers which several estate managers estimate account for roughly one-forth of the total production in Kabarole. Tea grown on smallholder land in Kabarole is a government priority, with support provided for the commercial production and distribution of plantlets to smallscale farmers (Mbarara 2004; Masinga 2004). Lack of adequate transport infrastructure however is seen to hamper this effort, with small-scale producers in many cases having to physically carry their produce to the tea processing centers (Cafedirect 2004). As well distance and road conditions make larger-scale transport of tea to the Kenyan port of Mombassa more costly for the tea industry in western districts like Kabarole (Masinga 2004).

The tea industry is one of the largest employers in the country. According to the Uganda Tea Association (2002), the industry employees 50,000 workers both indirectly and directly; this is three times more labor than the sugar industry and two times more labor than the coffee industry - the other leading export crops in Uganda. The high employment levels are a result of the labor intensive growing and harvesting processes involved. In addition, large amounts of firewood must be harvested in order to dry the tea leaves. According to a number of informants, the number of laborers per hectare of tea ranges from 2 to 2.5 individuals, which is consistent with the findings of Namara (1991) and USAID (2001).

\section{Time series analysis}

\section{Methods}

A time series analysis of remotely sensed images of two dates, 1955 and 2001, was performed to investigate the tea industry's role in shaping the landscape of the study area. ${ }^{4}$ The land cover data for 1955 was derived primarily from topographic maps (Dept. Lands and Surveys, 1969). Plantations are delineated on these maps thus enabling an

\footnotetext{
4 The landscape has been in flux over the 46 year period and it is likely that the vegetation in a number of areas has experienced multiple periods of conversion and succession. Although the two dates fail to capture this dynamic nature of the landscape, the limitation is unlikely to lead to incorrect inferences because the objective here is to understand general aggregate trends in land cover change.
} 
analysis of plantation change dating back to $1955 .{ }^{5}$ A vector coverage representing forest, non-forest, and tea estates was created by digitizing the topographic maps. ${ }^{6}$

Land cover for 2001 was estimated from a supervised classification of Landsat Thematic Mapper TM imagery (Landsat 7, 2001). A total of 99 training samples were collected, 68 of which were used to create 'areas of interest' while the remaining 31 were used for an accuracy assessment, resulting in 87 percent accuracy. Three land cover classes were derived, 1) forest: which includes fully stocked tropical high forest, degraded tropical high forest, and eucalyptus plantations, with canopy closure of at least 60 percent (approximated visually); 2) tea: both smallholder cropped areas of at least $30 \mathrm{~m} 2$ and large estates (only areas in leaf were included); ${ }^{7}$ and, 3 ) an 'other' category comprising a mix of smallholder agriculture, pastureland, grassland, bodies of water, urban, and degraded forest/secondary growth with canopy closure less than 60 percent. Following classification, the satellite imagery was converted into a grid and cross tabulated with the 1955 grid. ${ }^{8}$ Results of the cross tabulation are summarized in Table 1.9 Elevation and slope were not included in the land cover change analysis because the area is characterized by gentle topography.

To examine the influence of government enforcement of conservation laws on land use decisions of the tea industry, administrative boundaries of KNP were digitized and a separate land cover change analysis was conducted for the area within the park boundaries. Inferences drawn from this exercise take into account the fact that the

${ }^{5}$ Although the type of plantation is not specified, it is almost certain that they are tea because most of the coffee was replaced with tea in the 1940s.

6 This was done using IMAGINE and Feature Analyst software. The coverage was attributed in the TABLES module of ARC/INFO. The attributed vector coverage was converted into a grid of 30 meter pixels to be compatible with the 2001 image. A portion of the original photographs from which the topographic maps were derived was used to analyze the classification methods used in the derivation of the topographic sheets.

${ }^{7}$ A few difficulties were encountered during the classification process. For example, it was impossible to detect a portion of the larger tea estates. This was due to the fact that certain stages of tea growth reveal spectral signatures virtually identical to that of bare soil. Every three to four years tea fields are coppiced to the point where no green biomass remains, exposing the soil. In addition, newly planted fields reveal high soil reflectivity, as the plants are very small and covered with dry palm leaves. Overall this results in an underestimation of the area devoted to tea. Also the number of training samples collected in relation to the size of the study area was relatively low. However the likelihood of generating gravely incorrect inferences from the data is small because the overall goal of the land cover change analysis is to better understand the basic trends of land use/cover change associated with the tea industry.

8 This was done with ARC/INFO GRID.

9 Sources of possible error of the cross tabulation are as follows. Because the two dates were derived from different data sources (air photograph interpretation and satellite imagery) there could be some discrepancies between feature representations. In addition, the topographic map 56/4 (northern half of study area) has a slight uniform shift due to errors of air photo interpretation, which led to the emergence of sliver polygons on the output grid. 
boundaries of the park as well as its conservation status have varied somewhat over time, but have been under protected status of some kind since the 1930s.

Worth noting here is a period of tea abandonment and how this fits into the land cover change analysis. From the early 1970s to the mid 1980s the tea estates of the study area were largely abandoned due to economic and political difficulties. Multiple informants indicated however that the abandoned tea estates were not converted to another land use because residents were afraid of punishment from either the government or the owners of the tea estates when they returned. According to elderly informants, virtually every estate in the study area grew into "forests of tea" and it wasn't until around 1986 when rehabilitation began, that these were cut down, used as firewood, and replaced with new tea fields. Thus the abandonment phase represents a pause in tea production rather than a drastic landscape change, offering an element of continuity to this rather odd time period.

\section{$\underline{\text { Key-informant interviews }}$}

To understand the driving forces of land use, 136 key-informant interviews with plantation owners, forestry officials, smallholders, and other relevant individuals were held. ${ }^{10}$ Interviews ranged from one-on-one meetings with representatives from the tea estates to group discussions with as many as fifteen tea estate employees at a time. Interviews followed an unstructured format; which is useful for exploring complex socioeconomic issues (Devereux and Hoddinott, 1993). To facilitate discussion and identify areas of various land cover change, printed multi-temporal composites of the 1955 and 2001 images at a scale of 1:40,000 were brought into the field in hardcopy form. These composites allowed those being interviewed to see where land cover changes have occurred over time. Results from the interviews are linked to the results of the time-series analysis to better understand the socio-political aspects of land cover change in the area.

General fields of inquiry for the interviews included reasons for choosing (or not) to participate in tea estate labor, area of origin for tea estate employees, opinions of Kibale National Park, history of estate labor, migrant-local relations, population density trends, and general relations among various groups of interviewees. Different tenure regimes were covered, including the customary tenure of migrants and non-migrants, private tea holdings under formal state tenure, and common property; as well as the interaction of these. Also covered in the study were the different areas where workers lived, including worker camps on estates and in villages. Efforts were concentrated on villages and estates

\footnotetext{
${ }^{10}$ Interviews included, approximately 50 tea estate laborers (in estate fields and worker camps); (19 tea estate administrators (factory managers, human resource managers, field supervisors, engineers, and nursery managers); approximately 50 village residents; 12 patrol rangers of Kibale National Park (employees of the Uganda Wildlife Authority); three government administrators of Kibale National Park; two district officials (Population Officer and the District Agricultural Officer); in addition the worker camps of Kihingami, Mujugu, Nyarubira, and Rwetibabe were visited; and the managerial staff from Kihingami, Mpanga, Kiko, Munobwa, Mabale, Rwetibabe, TAMTECO, UTGC and Kirima estate factories and offices were interviewed.
} 
closer to the KNP boundary. From Figure 2 it is evident that the location of the interviews was concentrated primarily along the northern and western borders of KNP. This is because these are areas of higher tea estate concentration. However, non-tea producing villages were also visited along the southern border of KNP. Information from the latter enabled a general comparison between tea and non-tea areas. Worker camps and estates visited are not included in Figure 2.

\section{Land Cover Change Analysis}

Table 1 shows for the study area that from 1955 to 2001 an estimated 9,387 hectares were deforested and 15,032 hectares were reforested resulting in a net gain in forest area of 5,645 hectares. This would seem to imply that OFE is having a positive effect on forest area, or that at the very least not a negative effect. And in this regard the land cover change analysis would appear to support the literature. However a closer examination reveals a different story. The land cover change analysis also indicates that the majority of reforestation (72 percent) has occurred within the KNP boundaries while the majority of deforestation ( 82 percent) took place outside the KNP boundaries (Table 1). Figure 3 reveals that most of the reforestation has occurred in the central core area of KNP and along the southwestern boundary of the forest. This is due to a number of factors. First, since the eviction of 'encroachers' from the game corridor in 1992 (currently the southwestern portion of KNP), there has been an active tree-planting project in the area. Secondly, the non-forest polygons within the forest core represent natural grasslands that were maintained with controlled fires until 1993. Thus, many of these grasslands are likely converting to forest. Third, prior to 1993, Kibale forest served as a source of hardwood timber and was logged on a 70-year polycyclic felling cycle (Chapman et al., 1998). Logging has for the most part ceased since 1993 and many formerly logged areas are in a stage of advanced secondary growth showing as forest in the 2001 classification.

That state enforcement of forestry and conservation laws has played a role in shaping land use decisions of the tea industry in the area is supported by the land cover change analysis. Table 2 and Figure 4 indicate that all but 21 hectares ( 4 percent) of the 501 hectares of forest to tea conversion occurred outside the current boundary of KNP.11 However not evident from the land cover change analysis is the clearing of wetlands and remnant forests (two land cover features that fall into the 'other' land cover class) lying outside KNP boundaries. Figure 5 shows a wetland near Sebitoli that was cleared by a tea company and is in the process of being drained. Once drained, the area will be converted to a eucalyptus plantation (low lying wetland areas are not suitable for tea). Due to favorable aromas and a fast growth rate, eucalyptus is the preferred fuel wood for drying

\footnotetext{
${ }^{11}$ Although the boundaries have changed over the years, most of the change has occurred in the non-tea producing southern region of the park.
} 
tea at the factories. ${ }^{12}$ As tea production increases so does demand for eucalyptus. To meet the growing demand some companies establish eucalyptus plots in cleared areas on the estates to minimize environmental damage, but others, Rwenzori Commodities in particular, opt to convert wetland areas outside KNP, which is met with little resistance from the government. ${ }^{13}$ Despite the fact that wetlands are officially protected by the National Environmental Statue of 1995 (NEMA, 2001), enforcement of these laws is problematic. This is partially a result of recent decentralization efforts granting authority to govern natural resources outside protected areas to the District Environmental Officer (DEO), which can have limited funding and capacity.

An additional aspect of wetland management is that they are common property under customary tenure regimes, with user rights based on proximity - one can harvest from the area he/she resides closest to. If a single entity owns all the land around a wetland or gallery forest, its fate is at the discretion of the landowner, which in the case of the wetland shown in Figure 5 is a tea company. Not surprising, wetland conversion to privately owned eucalyptus plots has sparked some hostility towards the tea industry among the surrounding smallholder communities because wetlands represent one of the only remaining natural resources from which communities are legally able to harvest building materials, firewood, fish, and other materials.

\section{Labor Source}

\section{Local Versus Migrant}

Virtually every informant indicated that the majority of the workforce, both skilled and unskilled, is comprised predominately of migrant workers. The bulk of skilled laborers originate from Kenya, Asia, Europe, and other districts in Uganda, while rural farmers occupy the unskilled positions. For the most part, the Batoro, the local ethnic group, shun the idea of participating in tea estate labor. This is due to both monetary and nonmonetary considerations. The Batoro population residing near the estates is comparatively better off than the inhabitants of poorer districts of the country due to a history of regional economic development and a relative abundance of arable land. Part of this may be connected to the presence of shops catering to the needs of the teas estate laborers. To the smallholder with sufficient land, food, and income, working on the tea estates is not an attractive option excluding, infrequent short-term work as a means to supplement income. The wages are not high enough to offset the undesirable working conditions of the estates.

\footnotetext{
12 Factory managers admitted to using natural forest to subsidize the fuel wood due to shortages of eucalyptus.

13 Unfortunately, eucalyptus is not a separate land cover class in the land cover change analysis because eucalyptus was not classified on the (1955 topographic maps. Therefore, this element of tea driven landscape change was not captured.
} 
Cultural values towards agribusiness labor and work ethic also appear to influence decisions. Many Batoro informants claimed that they have never considered working on the tea estates because it is looked down upon in Batoro culture or simply because it is "too much work," or "the Batoro aren't good at that kind of work." The different apparent work ethic between the Bakiga, the dominant migrant community, and the Batoro are well understood by the estate managers, most of whom prefer to hire Bakiga. This perception is understandable given the comparatively greater poverty and hence desperation of the migrants. However the few local residents that do work on the tea estates reported that they farm less since the time of employment. Consistent with OFE theory, informants from the local villages of Kanyansohera and Rwama reported an overall decrease in agricultural activity due mainly to time constraints. Those residing close to the forest boundary were more likely to pursue labor on the tea estates due to frustrations associated with crop raiding by wildlife, a significant trend when considering people-park relations. However, other informants commented that it is not uncommon for a villager to invest the money earned into subsistence agriculture or cash crops. Often this investment involved purchasing new land for expansion of holdings.

According to estate managers, migrant (primarily Bakinga) workers constitute anywhere from 50 to 90 percent of the labor force, with most estimates closer to the latter. These estimates appear to be accurate based on interviews and discussions with laborers and residents from neighboring villages. Migration of Bakiga (primarily from Kabale District near the Rwanda border, Figure 1) into Kabarole district is not a recent phenomenon. The 1969 census, for example, reports a net out-migration from Kabale of 100,000 people to other districts within Uganda. Large scale migration of Bakiga into Kabarole the area began as early as the 1940s and is rooted in a number of economic, political, and social push and pull factors, many of which remain in place today.

Nearly every Bakiga migrant interviewed claimed that the lack of sufficient arable land was the primary reason for leaving his or her home area. Land shortages in southwestern Uganda are well documented. The most recent census available at the time of this study (1991) reports a population density of 246 people per square mile in Kabale compared to the national average of 85 people per square mile (NEMA 2001; also Aluma et al 1989 for similar population densities). The high population density of southwestern Uganda is due to a number of factors, including the absorption of refugees from neighboring Rwanda and Democratic Republic of Congo, steep topography that limits the amount of arable land, and customary land tenure systems which divide land among all surviving sons resulting in land fragmentation. With very small plots, land is cultivated intensively, often skipping fallow periods and resulting in lower agricultural yields and degraded soils (Aluma et al., 1989).

The tea industry near KNP has a long history of serving as a pull factor. In response to the lack of interest among the indigenous Batoro, the tea estates have looked for a likely source of inexpensive labor. The more marginalized Bakiga population of the southwest 
have proved optimal. In the 1940s tea companies aggressively recruited Bakiga workers and have periodically provided transportation to the estates in Kabarole. But perhaps the strongest pull factor is the Bakiga themselves. Many arrive alone to work on the estates but soon notice the relative land availability and invite their relatives and friends to Kabarole, facilitating further in-migration. Over time, in-migration of Bakiga and other ethnic groups from less developed and/or overcrowded districts is expected to increase along with the growth of the tea industry.

\section{Population growth and tea}

Since at least 1969, Kabarole district has had one of the highest population growth rates in the country. Between 1969 and 1980, the annual growth rate was 4.7 percent - the third highest nation-wide. Kabale (source of the migrants), by contrast, had a growth rate of only 1.2 percent for the same time period (MFEP, 1992). More recent figures for Kabarole show a population density increase from 92.1 persons per square kilometer in 1991 to 111.5 persons per square kilometer in 1998 (Kabarole District Report, 2000). Multiple informants attributed the high growth rates of Kabarole to the in-migration of Bakiga. This is supported by the 1991 census, which shows that over 87,000 residents, or 12 percent of the total Kabarole population, originated from Kabale (MFEP, 1992) The Bakiga represent the most numerous single ethnic group (57 percent) among the migrant population (MFEP, 1992). The District Environmental Profile for Kabarole (NEMA, 1997) claims the Bakiga make up the second most populous ethnic group in the district behind the Batoro, representing 28 percent of the total population (NEMA, 1997). ${ }^{14}$ The demand for labor remains high due not only to the rapid expansion of the tea estates but also due to the unstable nature of the workforce due to high turnover, reminiscent of the situation on colonial estates as described by Ahluwalia (1995). Every tea laborer interviewed reported that their employment as a tea laborer is only temporary, and the majority expressed a desire to settle and farm.

\section{Spatial Patterns of Migrant Settlement}

All of the migrant workers living in the camps (located on the tea estates) expressed a desire to grow food crops to supplement their income, but most estates forbid any smallholder agricultural activity on their property. A few estates however, allow their workers to establish small plots, but forbid the planting of perennial crops or trees. Such plots are usually in low-lying wetland areas not suitable for tea production and thus not vital to the tea estate. These findings are consistent with those of Nabuguzi and Edmunds (1993). This limited agricultural activity suggests that the tea labor force residing in camps does not represent a group likely to exert pressure on KNP. However, the majority of workers consider their employment on the tea estates to be temporary and eventually plan to return to the agricultural lifestyle. Thus the constraints placed on the workers by

14 The discrepancies between the District Environmental Profile (28 percent of population is Bakiga) and the (1991 census (12 percent of population born in Kabale) are likely due to the fact that some Bakiga originate also from other districts (i.e., Rukungiri) and that many Bakiga are born in the Kabarole district, which was evidently not accounted for in the (1991 census. 
the estates do not appear to diminish a desire to return to smallholder agriculture, as revealed by the high turnover of the labor force.

Settlement of tea migrant laborers in the area is not a recent phenomenon. When the industry crashed in the 1970s many estate workers returned to their home districts, but a large number settled in the study area. Informants from every village visited reported that some portion of the village population were once migrant laborers, former employees, or related to former or current employees. In one example, Nyakabingo, a village bordering the northern edge of KNP, the village is composed almost entirely of former tea estate laborers or the descendants of former or current employees. A village elder in Kinyatale told a similar story. Nyabubale, Kanyansohera, Mukitoma, and Rwama also reported the settlement of Bakiga tea workers in the village. Other studies have recognized similar patterns around KNP (Aluma et al., 1989; Nabuguzi and Edumunds, 1993; and NEMA 1997).

Eager to resettle and with little capital, options of land acquisition for the migrant worker are often limited to those plots closer to the park boundary, which are highly devalued due to crop raiding by wildlife. One informant, a Bakiga migrant and former tea laborer with crops adjacent to KNP, purchased his land not knowing how extreme problems of crop raiding by wildlife were, and was eager to relocate further from the forest edge. The long-term residents of the area are accustomed to problems of crop raiding, reflected in the Batoro custom that seeks to strategically place migrant settlers between village crops and the forest in order to buffer their own crops from wildlife. Informants in Rwama, Mukitoma, and Sebitoli villages indicated that it is very common for Bakiga tea workers to purchase land neighboring the forest. These findings are consistent with those of Aluma et al. (1989) and Naughton-Treves $(1998 ; 1997)$ and correlate with results from a recent survey conducted by the World Conservation Union (IUCN) that found a disproportionately high population of Bakiga among parishes bordering KNP (IUCN personal communication). Such patterns are important in terms of pressure on forest resources not only because of the proximity of KNP, but also due to the high labor turnover on tea estates which has the effect of providing increasing numbers of exlaborers to the pool of migrants seeking to settle in a defined area between the Batoro and the KNP boundary. As well, there is general evidence that migrant settlers tend to clear more land than non-migrants (Uitamo, 1999; and Cligget et al., unpublished manuscript). Overall a combination of high levels of in-migration, an unstable labor force, and local encouragement of migrant settlement near the forest boundary, is likely to significantly increase human pressure on Kibale National Park and surrounding forest areas.

\section{Tea Buffer Zone}

While the tea industry is catalyzing both physical change and demographic change to increase human pressure on KNP, in other locations along the boundary tea plantations were found to have an unexpected influence on KNP protection. Because a number of plantations abut the KNP boundary directly (Figure 4), and wildlife neither consume tea 
nor often cross the large tea fields, the plantations serve as a very effective physical buffer between KNP and small-scale agriculturalists who might otherwise encroach on the forest. This buffer zone is perceived to be an effective tool for both limiting encroachment and improving people-park relations along portions of the KNP border by reducing problems associated with crop raiding by wildlife. Not surprisingly, UWA representatives interviewed consider the tea estates a valuable ally for the conservation of KNP. So much so that one forestry officer commented, "If it wasn't for the tea estates, the forest would not be here today." According to the Tourism Director and the Community Conservation Director, KNP management is considering a project to encourage smallholder tea production as means of improving people-park relations and improving the economic status of those living around the park. The possibilities for such a project look promising to some degree, as numerous out-growers already buffer their food crops using tea. However the buffer effect of tea needs to be balanced against the fact that tea plantations offer much less in the way of biodiversity compared to bush fallow agriculture. Naughton-Treves et al (1998) describes for the Kibale area how the defined boundary created by tea acts to isolate Kibale's ecosystem, and the differences in biodiversity between bush fallow and tea areas. Such buffer zone management is a topic of some discussion in the literature, revealing a wide array of circumstances and application (e.g. Tattari et al 2003; Nautiyal et al 2003; Goldman 2003).

\section{Long-Term Trends}

A few long-term consequences are likely to be associated with the physical and demographic changes induced by the tea industry in western Uganda. Multiple informants expressed concerns over the eventual creation of a landless peasant class due to the land acquisition practices of the tea industry. In order to escape the KNP forest edge, some smallholders are selling their land to tea companies well below market value. The decrease in arable land and available natural resources due to a combination of cash cropping, rapid population growth, tea estate expansion, and the conversion of wetlands and remnant forest outside KNP, is a concern that was variable among respondents. While the older more established residents expressed little concern over future land availability, the younger generation seemed very worried and many expressed hostility towards the tea estates due to their acquisition of arable land and natural resources. As the nonprotected natural resources continue to decline, resources in the park are likely to grow in value. In addition, as arable land becomes scarcer, land prices are likely to increase, which may lead to increased settlement near the forest where less expensive land can be found (Garrity et al., 2000). Already there are hints of resource and land shortages. One tea company representative commented that farmers have recently begun to encroach on the estate's eucalyptus plots for land and/or woody biomass resources. Another tea estate manager indicated that while land shortages may not be evident presently, in times of drought or other stress the ability of smallholders to cope will be severely limited. Increasing competition for land will likely foster negative views towards the KNP as many see little immediate benefits from the park. 
Rising ethnic tensions between the Batoro and the Bakiga was another concern expressed by a number of informants. Because the Bakiga are considered to be one of the more industrious ethnic groups of Uganda, they can make the indigenous Batoro population feel uneasy (Onyango-Obbo, 2002). Judging from conversations with members of the Batoro community, there is a general state of apprehension regarding the growing Bakiga population. In the village of Busimbi, for example, a village elder expressed concern over the incompatible customary land tenure systems between the two groups. Generally in areas of conflicting tenure systems, natural resource management becomes much more difficult because open access land tenure situations can develop (Unruh, 2002a).

A final issue addressed by informants is that of differing spatially-based attitudes toward KNP. Hostility toward the KNP among residents in the southern area of the Park was commonly expressed, while a more apathetic view was encountered in the northern area. These findings correlate with the survey conducted by IUCN in villages surrounding KNP (IUCN personal communication). According to the survey, residents more active in tea production, whether as a laborer or an out-grower, held very little interest in taking part in a participatory management plan for the reserve. This lack of interest is may be due to a combination of greater economic activity in the tea producing areas (i.e., smallholder tea production, more access to markets via tea roads, proximity to the large nearby town of Fort Portal) and the buffer zone created by the tea estates, making access to the park more difficult. Villages along the non-tea producing areas of the southern boundary of the park however, are interested in gaining more access to the resources of KNP and are actively involved in participatory management plans. Which relationship is better from a conservation standpoint is difficult to say. On one hand, the lack of interest could be beneficial in that it may signify less need to harvest from the park. However, it also means the loss of what could be considered the foundation of participatory conservation - that rural households depend on natural resources and will thus work to better manage them (Bliss and Gaesing, 1996).

\section{The Off-Farm Employment - Migration Relationship}

While other studies have considered the OFE - migration relationship generally (e.g., Garrity et, al., 2000; Kaimowitz et, al., 1998; Chomitz and Griffiths, 1996; and Ericson et, al., 1999), the focus here is to examine in a more nuanced fashion the relationships between migrants and: local communities, land cover change, settlement patterns, protected vs. unprotected forest areas, labor stability, and livelihood security as important operative aspects of the OFE - conservation paradigm. More than anything these relationships highlight the importance of site-specific features of particular OFE conservation cases. Generally, attracting migrants should be a concern for OFE advocates because in-migration into forested frontier areas represents a major demographic factor underlying smallholder agricultural expansion and deforestation (Geist and Lambin, 2001). 
The pressure exerted by migrants on unprotected forests in the KNP area as they pursue agricultural settlement is of particular importance. Migrants tend to practice more exploitive land use patterns due to difficulty in securing tenure rights, making them less likely to invest in intensification measures and more likely to clear more land than is needed for agriculture in the near term for purposes of making their claim clear. In addition, they may introduce customary land tenure systems foreign to the local community, encouraging competition for resources in what can become an open access 'tragedy of the commons' land tenure situation (Rudel, 1995). Finally, empirical evidence suggests that once people begin moving into an area and settle, it is very difficult to reverse the trend (Ericson et al., 1999). In this context the lack of a more in-depth examination of issues of migration in an OFE context is surprising considering the links between migration to frontier areas and deforestation (Aluma et al., 1989; and Uitamo, 1999).

The tea industry's dependence on migrant workers stems mainly from the lack of interest among the local community, which is a result of both monetary and non-monetary factors. The literature acknowledges that wages must be higher than current incomes if local farmers are to consider pursuing an off farm employment opportunity (Angelson and Kaimowitz, 1999; and Ahluwalia, 1995). The results of this research generally concur with these findings because low wages were one factor in local smallholder decisions to avoid estate labor. But the present analysis also examines non-wage related issues as important factors in decision-making as well. The long-term security of the agricultural lifestyle is significant in smallholder decision-making. Elastic global markets can result in very volatile fluctuations in demand, adding to the instability of working at a commercial plantation. Unhealthy working conditions due to the use of under-regulated chemical pesticides and monotonous physically demanding work can also discourage individuals from working at a plantation (UNEP, 2001). In times of political and/or economic instability, customary tenure and household agricultural food production constitute important forms of insurance and security (Unruh, 2002b; Williams and Karen, 1985). The highly volatile political and economic history of Uganda and the KNP area (Congo, Rwanda) has only strengthened this notion among smallholders, including migrants. Access to land has proved to be the most dependable source of capital and insurance, and hence household food security over the years, and is an important sign of wealth. Cultural values towards land are reflected in a phrase heard numerous times during the research, "land is life." Abandoning a lifestyle based largely on connection to land, conflicts with aspirations for food and livelihood security. Lee et al. (2001) acknowledge, "[t]he overriding objective of rural households is to secure a sustainable livelihood." The security and predictability associated with smallholder agriculture and land ownership is one reason cash cropping one's own land is preferred over estate labor as a source of income, as it does not require the sacrifice of this security. If attractive onfarm employment exists for the local smallholder, as is the case here with highly subsidized tea production, there is bound to be more resistance to join the off-farm employment labor force. Instead such a situation will encourage the clearing of additional 
land to pursue both food and cash cropping (also Chomitz and Griffiths, 1996). Thus the notion of 'improvement' with regard to wages needs to be recognized as only a partial incentive, particularly if local communities are not impoverished, and are more or less satisfied with current livelihoods.

Factors influencing migrant workers to settle as opposed to remaining an employee of the tea estates or returning to home areas are also important when considering demographic trends and land cover change around KNP. Like the Batoro, non-monetary issues influence migrant workers. The Bakiga are skilled agriculturalists with cultural ties to agriculture and land ownership, and are acutely aware of the inherent worth and security of land, as reflected in the long history of land shortages in southwestern Uganda where they originate (Turyahikayo-Rugyema, 1974). Such a history of land shortages encourages them to more aggressively seek land to cultivate in the KNP area, than if land shortages were not a problem in their home area. This presents a particular dilemma for the relationship between OFE, migration, and conservation. If those most drawn to OFE opportunities are agriculturalists from areas experiencing land shortages, then this is arguably the population that will be most aggressive about seeking new agricultural land in the area of OFE; just the opposite from the desired outcome in terms of OFE and conservation. For the Bakiga, employment on the tea estates is viewed as a temporary phase until the laborer can return to the security and familiarity of the smallholder agricultural lifestyle. The end result is in an unstable workforce requiring a constant influx of migrant workers and an increase in smallholder agricultural expansion. This resembles the labor force of Uganda's sugar industry as described by Ahluwalia (1995).

Such patterns of population change and settlement appear to overwhelm any conservation benefits from the relatively small-scale employment of local Batoro smallholders. However, beyond the employment context, the picture becomes less clear. Unintentionally, the tea has served as a physical buffer along some parts of the KNP boundary, acting as a sort of fence keeping wildlife in and people out. This is a sitespecific phenomenon, contradicting the dominant narratives regarding both the role of cash cropping and agribusiness in deforestation, and highlights the need to consider the intricacies attached to specific types of development.

\section{Conclusion}

The majority of previous studies investigating the conservation potential of off-farm employment have examined land use as a function of income. While such an approach remains important, it fails to account for the broader scope of change that often accompanies off-farm employment development. Findings from the present study suggest that when considering the conservation potential of off-farm employment, it is necessary to examine both social and physical change over various spatial and temporal scales. It was found, for example, that among a few villages within the study area, employment on the tea estates led to a decrease in agriculture near the forest boundary. However, the conservation benefits associated with this are likely to be offset by the 
broader physical and demographic changes associated with the tea industry, namely the increasing migrant population and degradation of forest and wetlands outside the park. Furthermore, the most significant contribution to conservation, the tea buffer zone, is not directly related to OFE development and exemplifies the need to consider a broad scope of change and the particulars attached to each specific case. We argue that while off-farm employment may hold potential for integrated conservation and development, it should not be considered a broad solution generally applied, because the conservation potential, or lack there of, resides in the specific local circumstances.

\section{Bibliography}

Ahluwalia, D.P.S. (1995). Plantations and the Politics of Sugar in Uganda. Kampala, Uganda. Fountain Publishers.

Aluma, J. (1989). Settlement in Forest Reserves, Game Reserves, and National Parks in Uganda. Land Tenure Center, University of Wisconsin, Madison.

Angelson, A., and Kaimowitz, D. (1999). Rethinking the Causes of Deforestation: Lessons from Economic Models. The World Bank Research Observer, 14, 73-98.

Beaumont, P. and Walker, R. (1996). Land Degradation and Property Regimes. Ecological Economics 18, 55-66.

Bilsborrow, R. et al. (2001). Research Overview: Agricultural Colonization, Settler LULC Dynamics, and Secondary Plant Succession: Factors Influencing Land Fragmentation, Carbon Sequestration, and Landscape Structure in the Ecuadorian Amazon. www.unc.edu/depts/geog/lcsal/ecuador ro.html visited April 15, 2002.

Bliss and Gaesing. (1996). Land Tenure Systems in Focus - Lessons Learned, Challenges and Options for the Future. GTZ working paper from web site www.gtz.de/orboden/ tenure/te3 1.htm visited April 15.

Bluffstone, R. (1993). The Effect of Labor Market Performance on Deforestation in Developing Countries under Open Access: An Example from Rural Nepal. Journal of Environmental Economics and Management, 29, 42-63.

Cafedirect (2004). Uganda. www.cafedirect.co.uk/growers.uganda tea.php.

Chapman, C.et al. (1998). Long-Term Effects of Logging on African Primate Communities: A 28-Year Comparison From Kibale National Park, Uganda. Conservation Biology, 14, 207-17. 
Chomitz, K. and Griffiths, C. (1996). Deforestation, shifting cultivation, and tree crops in Indonesia: Nationwide patterns of smallholder agriculture at the forests frontier. Environment, Infrastructure, and Agriculture Division Policy Research Department, The World Bank, Washington D.C.

Cropper, M. and Griffiths, C. (1994). The Interaction of Population Growth and Environmental Quality. The American Economic Review, 84, 2.

Department of Lands and Surveys, Uganda (1969): Map No: 66/2, Map Name: KAHUNGE, Scale: 1:50,000, Projection: UTM, Aerial Photography (1955), Publisher: Department of Lands and Surveys, Uganda, (1969); Map No: 56/4, Map Name: FORT PORTAL, Scale: 1:50,000, Projection: UTM, Aerial Photography (1955) (majority) and (1950), Publisher: Department of Lands and Surveys, Uganda, (1969); Map No: 67/1, Map Name: NKOMA, Scale: 1:50,000, Projection: UTM, Aerial Photography (1961), Publisher: Department of Lands and Surveys, Uganda, (1969); Map No: 57/3, Map Name: KYENJOJO, Scale: 1:50,000, Projection: UTM, Aerial Photography (1961), Publisher: Department of Lands and Surveys, Uganda.

Devereux, S and Hoddinott, J.eds. (1993). Fieldwork in Developing Countries. Lynne Rienner Publishers, Boulder, CO.

Ericson, J., Freudenberger, M., Boege, E. (1999), Population Dynamics, Migration, and the Future of the Calakmul Biosphere Reserve. Occasional Paper No. 1. Program on Population and Sustainable Development and American Association for the Advancement of Science.

Feeney, P. (1998). Accountable Aid. Oxfam, London.

Garrity, D. Amoroso, S. Catacutan, D. (2000). Innovations in Participatory Watershed Resource Management to Conserve Tropical Biodiversity. CGIAR Document. Website visited May 2, 2002. http://www.icraf.cgiar.org/sea/Landcare/Data\%20Papers/ 3InnovPart/InnovPart.pdf

Geist, H. and Lambin, E.F. (2001). What drives tropical deforestation? A meta-analysis of proximate and underlying causes of deforestation based on sub national case study evidence. LUCC International Project Office: Louvain-la-Neuve.

Godoy, R. Wilkie, D. Franks, J. (1997a). The Effects of Markets on Neotropical Deforestation: A Comparative Study of Four Amerindian Societies. Current Anthropology, 38, 875-878. 
Godoy, R. et al. (1997b). Household Determinants of Deforestation by Amerindians in Honduras. World Development, 25, 977-87.

Goldman, M. (2003). Partitioned nature, privileged knowledge: community-based conservation in Tanzania. Development and Change, 34, 833-862.

Hardner, J. and Rice, R. (2002). Rethinking green consumerism. Scientific American. May 2002, 286, p. 88.

Holden, S. (1992). Peasant household modeling: Farming systems evolution and sustainability in northern Zambia. Agricultural Economics, 9, 241-267.

Kaimowitz et al. (1998). Considering the impact of structural adjustment policies on forests in Bolivia, Cameroon and Indonesia. Unasylva, 49, 57-64.

Landsat 7 (2001). Scene ID: LE7173060000100950. Platform Landsat 7, Acquisition Date: 9 Jan 2001. Path: 173, Row: 60. Cell size: 30m. Registration: 26 control points, RMS: 0.607 .

Lee, D., Barrett, C., Hazell, P., Southgate, D. (2001). Assessing Tradeoff and Synergies Among Agricultural Intensification, Economic Development and Environmental Goals: Summary and Conclusions. In: D. Lee, and C. Barrett. (Eds.), Tradeoffs or Synergies? Agricultural Intensification, Economic Development and the Environment, New York, NY : CABI Publications.

Masinga, F. (2004). Green tea still runs half circle. Uganda Communication Commission, District Information Portal: Kabarole. www.dip.go.ug/news details.php?more=17

Mbarara, F. (2004). Tea growers in west cry foul. The Monitor (Kampala) January 30.

Ministry of Finance and Economic Planning (MFEP) (1992). The 1991 Population and Housing Census. Kabarole District. Statistics Department, Ministry of Finance and Economic Planning. Entebbe, Uganda.

Mugisha, S. (1994). Land cover/use around Kibale National Park. Analysis of 1988 aerial photographs, Uganda Forestry Department (Sheet no. BP 1939). MUIENR, RS/GIS Lab, Kampala, Uganda.

Nabuguzi, E. and Edmunds, D. (1993). Report on the Rapid Rural Appraisal for the Kibale Forest. Research Paper 4. Makerere Institute for Social Research, Kampala Uganda and the Land Tenure Center, University of Wisconsin, Madison. 
Namara, A. (1991). Labour Relations in the Tea Sector of Uganda: A Comparison of Estates and Smallholders. Research Paper, Institute of Social Studies, The Hague.

National Environment Management Authority (NEMA). (1997). Kabarole: District Environmental Profile. NEMA, Kampala, Uganda.

National Environment Management Authority (NEMA). (2001). District Population Densities and Protected Areas. NEMA, Kampala, Uganda.

Naughton-Treves, L. (1997). Farming the forest edge: vulnerable places and people around Kibale National Park, Uganda. Geographical Review, 87, 27-43.

Naughton-Treves, L. (1997). Predicting Patterns of Crop Damage by Wildlife around Kibale National Park, Uganda. Conservation Biology, 12, 156-168.

Naughton-Treves, L., Treves, A., Chapman, C., Wrangham, R. (1998). Temporal patterns of crop raiding by primates: linking food availability in croplands and adjacent forest. Journal of Applied Ecology, 36, 596-606.

Naughton-Treves, L. (1999). Whose animals? A history of property rights to wildlife in Toro, Western Uganda. Land Degradation and Development, 10, 311-328.

Nautiyal, S., Rao, K.S., Maikhuri, R.K., Saxena, K.G. (2003). Transhumant pastoralism in the Nanda Devi Biosphere Reserve, India - a case study in the buffer zone. Mountain Research and Development, 23, 255-262.

Onyango-Obbo, C. (2002). Here is What You Don't Know About the Kibaale 'Madness.' The Monitor, Kampala, Uganda.

Rudel, T.K., (1995). Do property rights make a difference? Open access, informal social controls, and deforestation in the Ecuadorian Amazon. Human Organization, 54, 187-194.

Shafik and Bandyopadhyay (1992). Economic Growth and Environmental Quality: Time Series and Cross-Country Evidence. World Bank Policy Research Working Paper, WPS 904, Washington DC: World Bank.

Shively, G. and Martinez, E. (2001). Deforestation, irrigation, employment and cautious optimism in southern Palawan, the Philippines. In: A. Angelsen and D. Kaimowitz. (Eds.), Agricultural Technologies and Tropical Deforestation, New York, NY: CABI Publications. 
Tattari, S., Schultz, T., Kuussaari, M. (2003) Use of belief network modeling to assess the impact of buffer zones on water protection and biodiversity. Agriculture, Ecosystems, and Environment, 96, 119-132.

Turyahikayo-Rugyema, B. (1974). The history of the Bakiga in southwestern Uganda and northern Rwanda, 1500-(1930. Ph.D. Dissertation. University of Michigan, Ann Arbor, USA.

Uganda Wildlife Authority (UWA). (1996). Kibale National Park Management Plan (1997-2001. http://www.facefoundation.nl/PDF/Ex_Sum_MP_KNP.pdf. Website visited May 9, 2002.

Uitamo, E. (1999). Modeling Deforestation Caused by the Expansion of Subsistence Farming in the Philippines. Journal of Forest Economics, 5, 99-122.

United Nations Environment Programme (UNEP). (2001). Climate change: billions across the tropics face hunger and starvation as big drop in crop yields forecast. http:// www.unep.org/Documents Website visited 2002.

Uganda Wildlife Authority (UWA). (1996). Kibale National Park Management Plan 1997-2001, Kampala, Uganda.

United States Agency for International Development (USAID) (2001). Tea Sub Sector Analysis: Findings and Recommendations. http://www.usaid.or.ug. Website visited October 6, 2002.

Uganda Tea Association (UTA) (2002). The Tea Industry in Uganda: Overview of the Tea Industry in Uganda, Kampala, Uganda.

Uganda Tea Growers Corporation (UTGC) (1998). Green Leaf Project: Technical

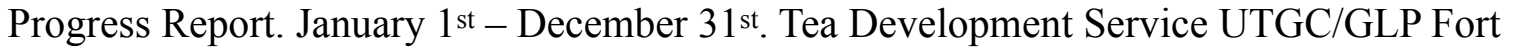
Portal, Uganda.

Unruh, J.D. (2002a). Local land tenure in the peace process. Peace Review, 14, 337-342.

Unruh, J.D. (2002b). Poverty and property rights in the developing world: not as simple as we would like. Land Use Policy, 19, 275-276.

Watts, D.P. and J.C. Mitani. (2001). Infanticide and Cannibalism by Male Chimpanzees at Ngogo, Kibale National Park, Uganda. Primates, 41, 357-365.

Williams, S. and Karen, R. (1985). Agribusiness and the small-scale farmer: a dynamic partnership for development. London, Westview Press. 
World Bank. (1993). Uganda Agriculture. World Bank Country Study. The World Bank, Washington, D.C.

\section{Topographic Maps}

1. Map No: 66/2, Map Name: KAHUNGE, Scale: 1:50,000, Projection: UTM, Aerial Photography (1955, Publisher: Department of Lands and Surveys, Uganda, (1969

2. Map No: 56/4, Map Name: FORT PORTAL, Scale: 1:50,000, Projection: UTM, Aerial Photography (1955 (majority) and (1950, Publisher: Department of Lands and Surveys, Uganda, (1969

3. Map No: 67/1, Map Name: NKOMA, Scale: 1:50,000, Projection: UTM, Aerial Photography (1961, Publisher: Department of Lands and Surveys, Uganda, (1969

4. Map No: 57/3, Map Name: KYENJOJO, Scale: 1:50,000, Projection: UTM, Aerial Photography (1961, Publisher: Department of Lands and Surveys, Uganda, (1969

\section{Landsat Image}

Scene ID: LE7173060000100950. Platform Landsat 7, Acquisition Date: 9 Jan 2001.

Path: 173, Row: 60. Cell size: 30m. Registration: 26 control points, RMS: .607 
Figure 1: Study Site Kibale National Park, Uganda

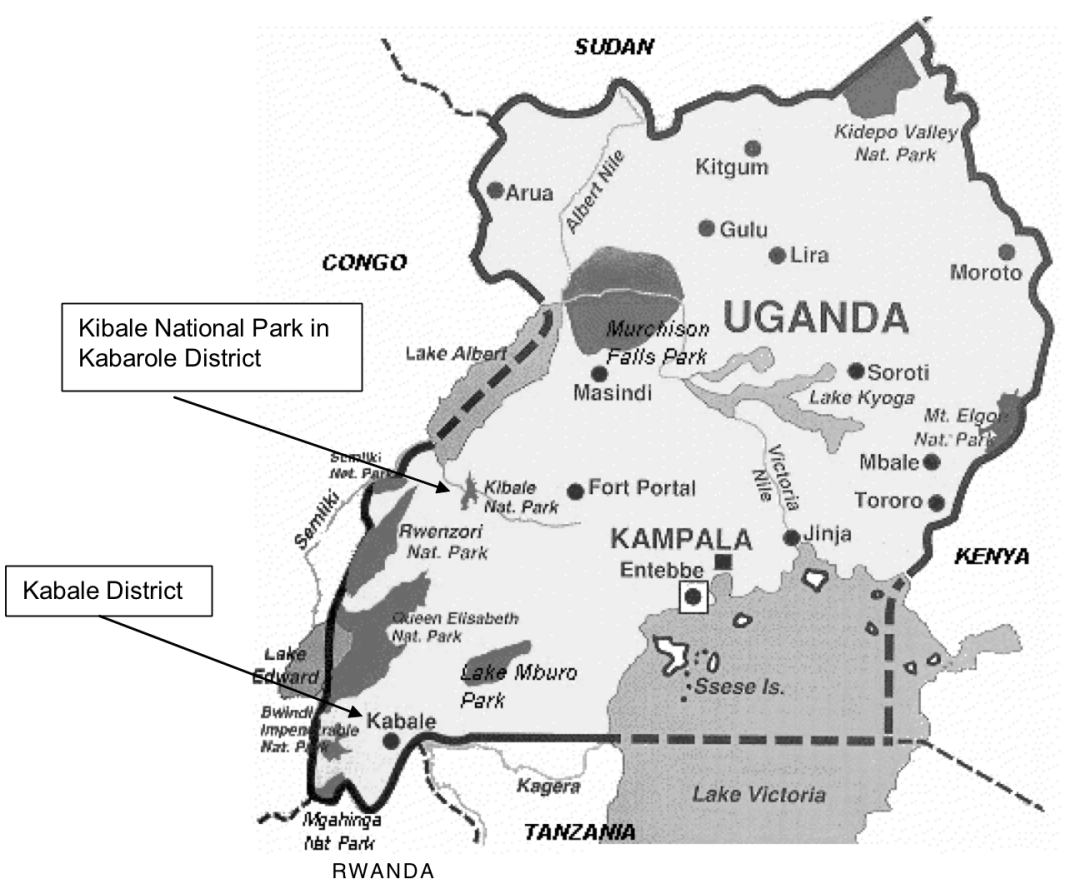

Source: http://www.africa-insites.com/uganda/ 
Figure 2: Study Sites

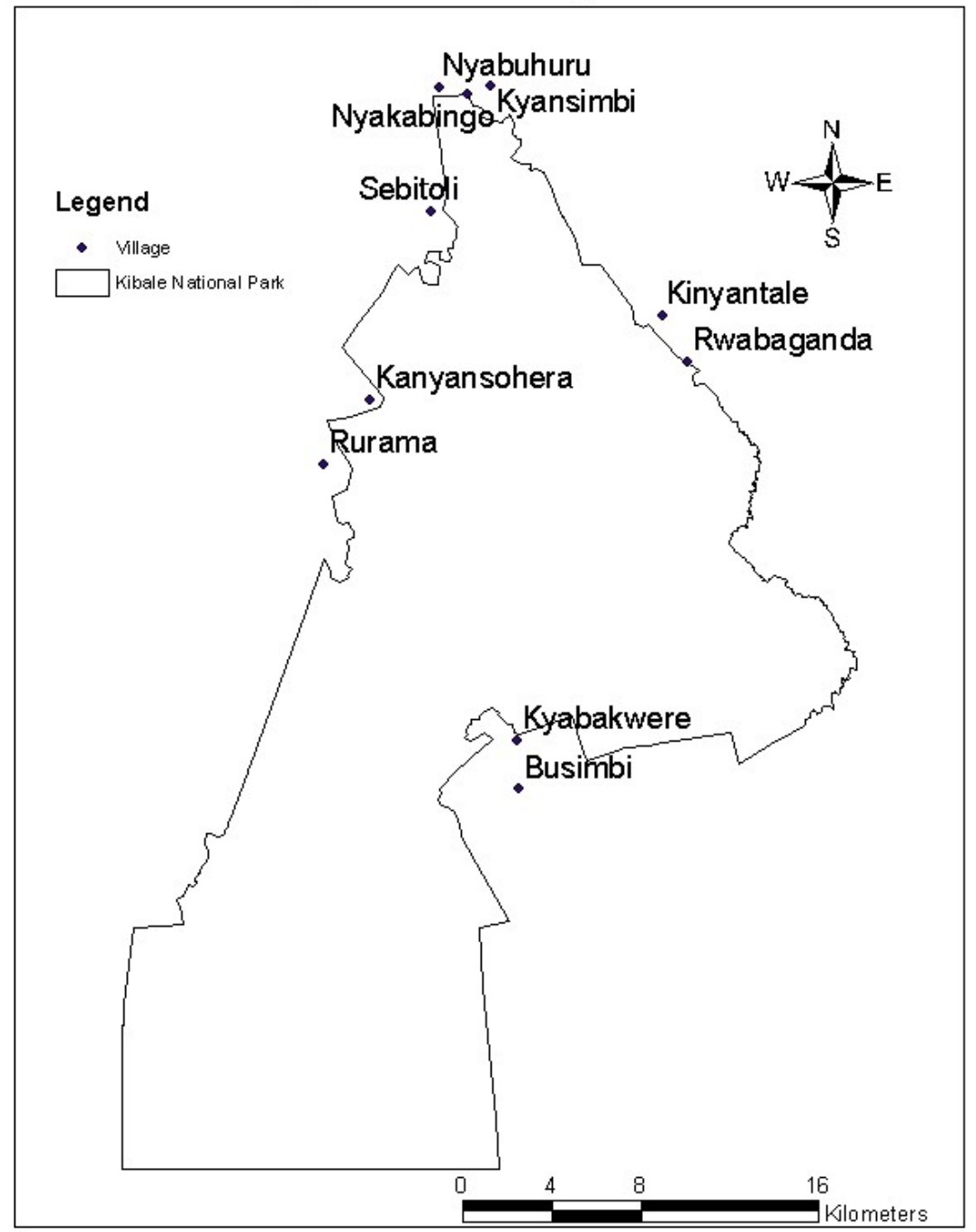

Only villages are shown. GPS data on tea factories,

worker camps, and trading centers were not collected 


\section{Figure 3: Forest Cover Change 1955-2001 Kibale National Park (KNP)}

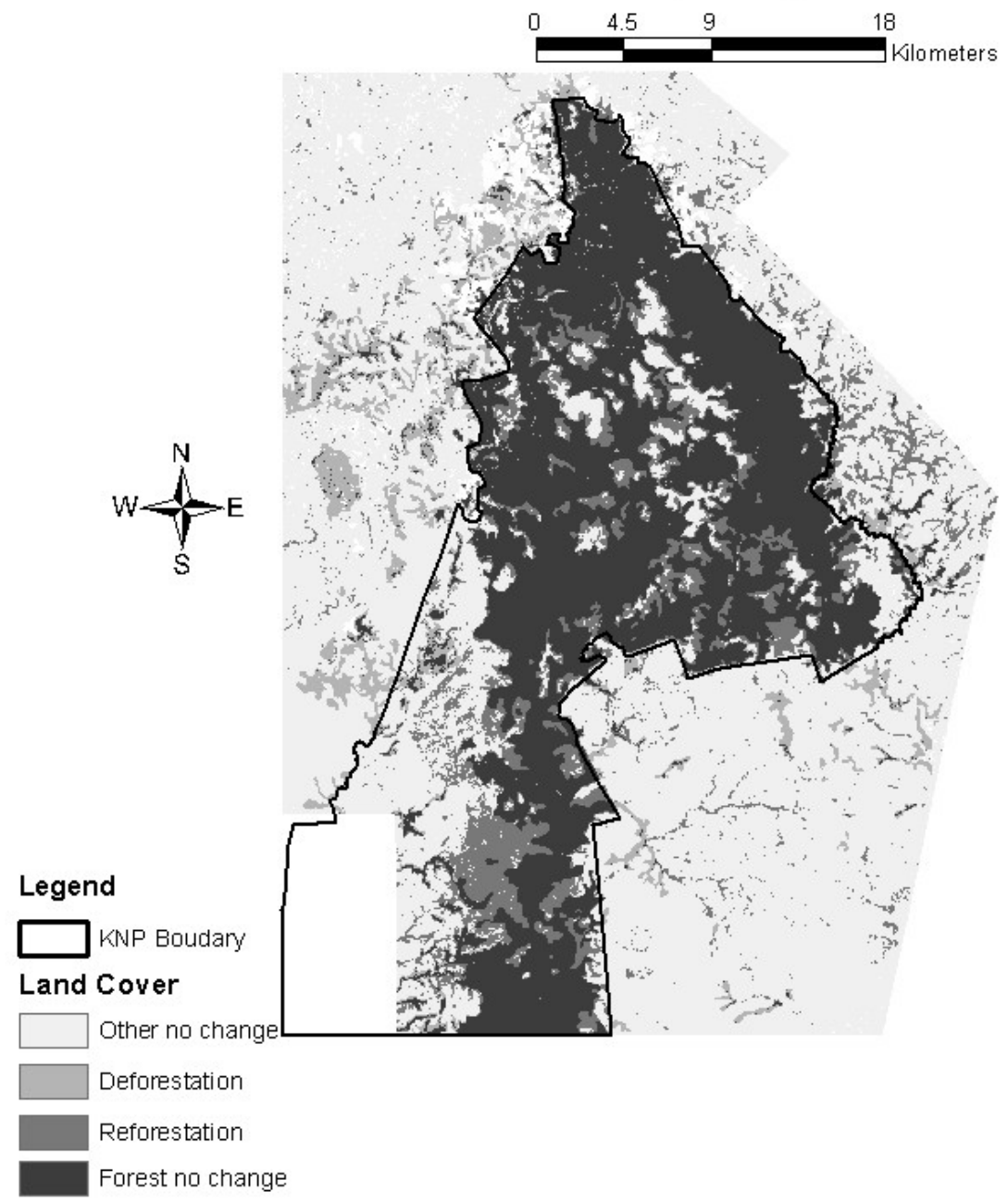

Note: Areas represented in white are related to tea and are represented in Figures 5 and 6 


\section{Figure 4: Tea Cover Change 1955-2001 Kibale National Park (KNP) Northen Region of Kibale National Park (KNP)}

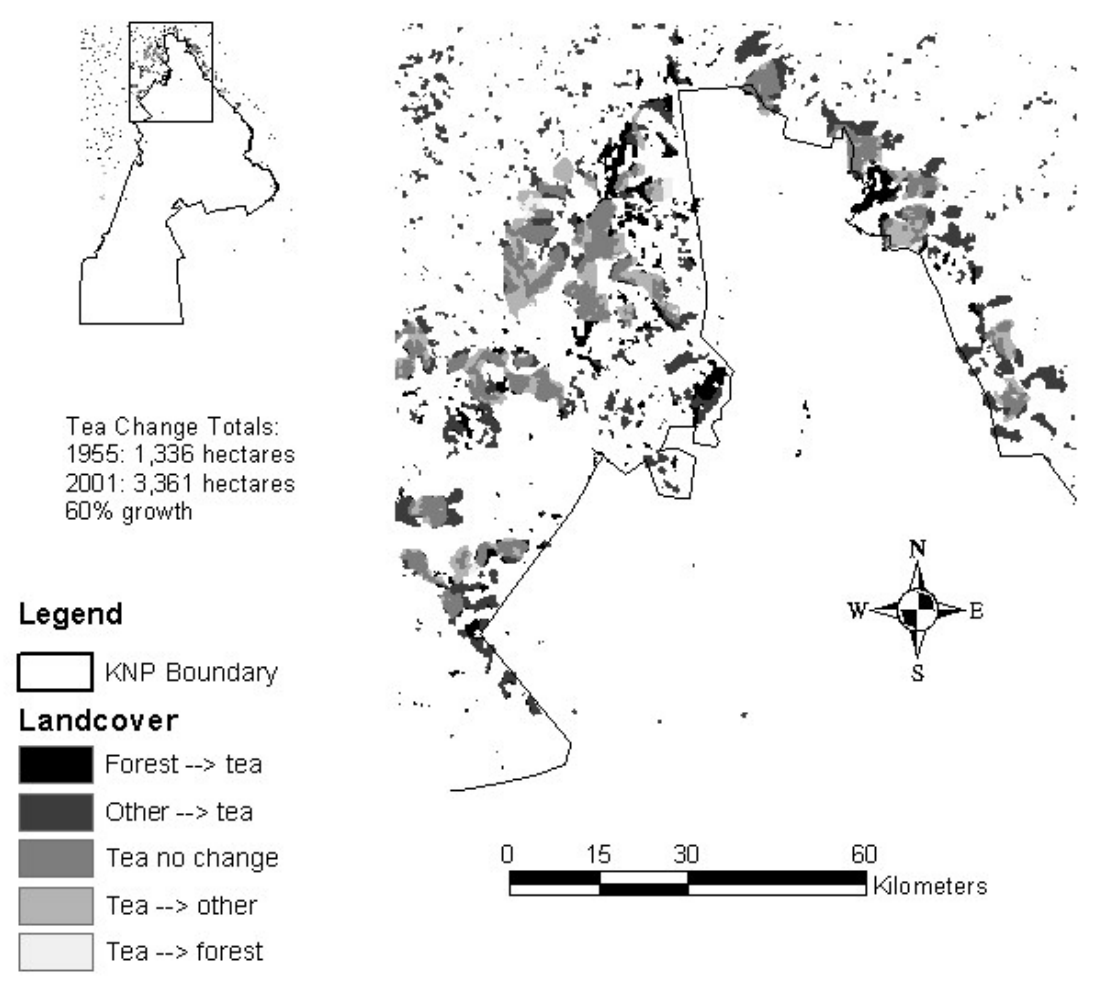

Table 1. Cross Tabulation for Forest Cover Change (1955 - 2001). Image results in Figure 3.

\begin{tabular}{l|l|l} 
Area & Percent Inside KNP & Outside KNP
\end{tabular}




\begin{tabular}{|l|l|l|l|}
\hline Deforestation & 9,387 & 18 & 82 \\
\hline Reforestation & 15,032 & 72 & 28 \\
\hline Net Gain & 5,645 & & \\
\hline
\end{tabular}

Table 2. Tea Change Summary (1955 - 2001) for Figure 4.

\begin{tabular}{|l|r|r|l|l|}
\hline & Hectares & $\begin{array}{l}\text { Total } \\
\text { Percentage }\end{array}$ & $\begin{array}{l}\text { Percent } \\
\text { Inside KNP }\end{array}$ & $\begin{array}{l}\text { Percent } \\
\text { Outside KNP }\end{array}$ \\
\hline Gain & & & & \\
\hline Forest $\rightarrow$ Tea & 501 & 19 & 4 & 96 \\
\hline Other $\rightarrow$ Tea & 2,143 & 81 & 2 & 98 \\
\hline Total & 2,644 & & & \\
\hline Loss & & & & \\
\hline Tea $\rightarrow$ Forest & 42 & 7 & & 7 \\
\hline Tea $\rightarrow$ Other & 582 & 93 & & 1 \\
\hline Total & 642 & & & 99 \\
\hline Net Gain & 2,020 & & & \\
\hline
\end{tabular}

